\title{
IMPACTS OF INSUFFICIENT INSTRUCTIONAL MATERIALS AND HIGHER EDUCATION SYSTEMS IN TEACHING BIOLOGY
}

\author{
Sutuma Edessa \\ Addis Ababa University, Addis Ababa, Ethiopia
}

\begin{abstract}
The research was conducted on the impacts of insufficient instructional materials and higher education systems of teaching biology on the qualification of graduates as outputs.

Data collection methods were through variables of in-depth interview questions and face-to-face observations, whereas both quantitative and qualitative methods were employed to analyze evidences comparatively.

Data sources were graduates of biology of different universities, who joined the post graduate diploma in teaching (PGDT) teachers training program of Addis Ababa University to be biology teachers, and evidences were gathered while the trainees were attaining the course biology teaching methods.

Interview questions were distributed to 200 trainees and respondents provided their judgments both in written or oral forms. The face-to-face observations were conducted on 20 of the trainees while conducting the tasks of biology teaching methods using observation checklists.

As a result, the impacts of the insufficient instructional materials and higher education systems were accounted for $56.83 \%$ and impacts on competence of the graduates of biology in performing expected biological tasks were accounted for $71 \%$ that made learners at an average $63.915 \%$ unsuccessful.
\end{abstract}

The research was concluded with great divorce of theory and practice due to the impacts of insufficient inputs of instructional materials and poor education systems, in which graduates ended with incompetence and joblessness.

Keywords: biology teaching, instructional materials, higher education.

\section{Introduction}

Instructional materials of higher education systems are designated contents of courses for transferring essential knowledge or skills to students that could enable learners to acquire factual ideas and develop professional career.

Instructional materials for the undergraduate program of biology for subject of this research includes course outlines, scripts, modules, reference materials, lab manuals, lecture notes, teaching aids and template guidance that learners use to conduct tasks practically. It was intended to search for the extent of provisions of learning facilitates and process of conducting the three corners of education systems focused on commitments of effective teaching, learning engagement and assessment techniques as well as professional and ethical responsibilities of the higher education systems.

Ashcroft, K. (2010), states that "faculties found it hard to cope with the increased class sizes and tend to rely on traditional teaching methods, which seem easier and are more familiar, but fail to meet market needs, increasing the danger of graduates unemployment or underemployment that is inherent in an expanding system". 
The impact was accelerated by the extension of the number of higher institutions and ignorance of educational facilities, adequate staffing with qualified professionals and effective education systems. In fact, the higher education system is a key bridge to provide lifelong experiences to graduates that enable them to perform skillful professional tasks after completion.

The issue of the study was identified while graduates of biology who joined the teachers training program of the Postgraduate Diploma in Teaching (PGDT) at Addis Ababa University had difficulties in understanding the content knowledge of biology and conducting designated tasks of classroom, lab and experimental activities.

Accordingly, the subject of the research was to find out answers to the question, why graduates of biology could not perform their professional career properly in relation to higher educational systems inputs and outputs.

The main aim of the research was to investigate the extents of the higher educational systems inputs (access to all instructional materials, learning facilities and the effectiveness of teaching) and attest with the skills and competencies transferred to do professional jobs as outputs.

\section{Methodology of Research}

Descriptive method was used to evaluate the impacts of insufficiency of instructional materials and teaching effectiveness of the higher education systems.

Data collection tools were in-depth interview questions and face-to-face observation, in which both quantitative and qualitative methods were employed to quantify and qualify empirical gathered data. Data sources were 200 graduates of biology, who joined the PGDT teachers training at Addis Ababa University in summer and regular programs. Interview questions that focused on the degrees of sufficiency of instructional materials and higher education systems were employed on 200 graduates of biology from different Universities and taking the PGDT training to be biology teachers. Responses to interview questions, both in oral and written expressions were collected and arranged in a table (Table 1).

Data collection through the face-to-face observation was employed on 20 of the 200 PGDT trainees of teaching biology using valued checklists set to assess the abilities and practical performances. Checklists were focused on measuring and valuing tasks that graduates of biology are expected to do practically like the classroom discussions, operation of microscopes and equipment, lab works and simple experiments individually or in groups.

Performances of the trainees of biology were valued and scored on how much of the tasks were properly done, tried and remained untouched or wasted were arranged in a table and described in percentile expressions (tables 2).

\section{Data Evaluation and Analysis}

The process of teaching needs consistency and innovation of instructional materials and resources to execute pertinent practical activities to produce professional workers after graduation. The recent inputs of the higher education systems clearly described that biology graduates had poor access to all instructional materials and resources.

The access to new course outlines was only about $65 \%$ of which $20 \%$ were old copies and lost $15 \%$ of the materials throughout their first degree attaining time of biology. 
Access to handouts was for about $52 \%, 33 \%$ depended up on lecture notes and lost the rest $15 \%$ was without. Access to reference materials was $29 \%$, about $31 \%$ used informal resources and $40 \%$ were completely without.

The access to new investigations of scientific researches of biology with the ongoing global level information was accounted for $60 \%$ whereas the rest $40 \%$ was impossible.

The teaching effectiveness of the higher education systems was $27 \%$ studentcentered approach, 59\% traditional mode and the rest 14\% was conducted through indirect contacts, whereas $85 \%$ of the learning hours were corrupted by none-educational appointments. Assessment techniques used in the higher education systems were $70 \%$ through termed exams, $28 \%$ quizzes and $2 \%$ assignments. The level of assets the higher education systems put was insufficient and distressing, showing higher impacts on all round development and capacity of biology graduates and made all things hard to cope with. Most of the teaching methods in use were traditional or teacher-centered, depended up on theory without practice and remained ineffective, in which students sat for writing exams without any feedbacks or information on the course they due to learn.

In summary of evaluation, educational inputs of the higher education systems (instructional materials, learning facilities and teaching effectiveness) was ended with $43.17 \%$ adequacy the rest $56.83 \%$ of insufficiency or wastage. The face-to-face observation was to attest the effectiveness of the higher education systems inputs in relation with the abilities of graduates of biology to conduct assigned tasks practically. Checklists were used to promptly value the performances of graduates to execute assignments within the contexts of higher education level and record scores in percentile expressions through conducted tasks of classroom discussion, operation of microscopes and uses of equipment, lab works, and actualization of simple experiments and skills of executing biological tasks as outputs. Accordingly, higher education graduates of biology overall conducted only $29 \%$ of tasks of biology effectively, but were unsuccessful in the rest $71 \%$ of the expected tasks.

The output of the higher education was ended with $71 \%$ impacts on graduates in every aspects of executing professional works showing that theory and practice were divorced and made graduates unsuccessful and incompetent. The facets to what extent graduates of biology put learnt knowledge into effect and conducted assigned tasks after graduation was only $29 \%$, which was irrelevant to the lost $71 \%$ of educational inputs comparatively.

\section{Results of Research}

The research was concluded with insufficiency of instructional materials and negative impacts on the competence of graduates based on the structure and methods of the research. As a result, the adequacy of inputs of the higher education systems was only $43.17 \%$ whereas the rest $56.83 \%$ of the inputs were insufficient showing great impacts. Graduates of biology performed only $29 \%$ of expected tasks of inputs and were unsuccessful to conduct $71 \%$ of expected biological tasks.

Overall, the cumulative impacts of insufficiency of instructional materials and higher education systems has accounted for $56.83 \%$ and the impacts on incompetence of graduates biology has accounted for $71 \%$ showing great divorce of theory and practice and lack of practicalities. 
Table 1. Responses to interview questions on the inputs of the higher education systems.

\begin{tabular}{|c|c|c|c|}
\hline \multirow{2}{*}{ Interview questions } & \multirow{2}{*}{$\begin{array}{l}\text { Variables of } \\
\text { inputs }\end{array}$} & \multicolumn{2}{|c|}{$\begin{array}{c}\text { The extent of higher educational } \\
\text { inputs }\end{array}$} \\
\hline & & The status of inputs & $\begin{array}{l}\text { Scores of } \\
\text { inputs }(\%)\end{array}$ \\
\hline \multirow{9}{*}{$\begin{array}{l}\text { To what extent did } \\
\text { you have access to all } \\
\text { instructional materials } \\
\text { for the BSC study } \\
\text { courses? }\end{array}$} & \multirow{3}{*}{$\begin{array}{l}\text { Course outlines } \\
\text { and guidelines }\end{array}$} & New course outlines & 65 \\
\hline & & Old copies & 20 \\
\hline & & Missing & 15 \\
\hline & \multirow{3}{*}{$\begin{array}{l}\text { Instructional } \\
\text { materials }\end{array}$} & Handouts & 52 \\
\hline & & Lecture notes & 33 \\
\hline & & Missing & 15 \\
\hline & \multirow{3}{*}{$\begin{array}{l}\text { References } \\
\text { materials }\end{array}$} & Campus libraries & 29 \\
\hline & & Individual searches & 31 \\
\hline & & Missing & 40 \\
\hline \multirow{6}{*}{$\begin{array}{l}\text { How do you judge the } \\
\text { teaching methods or its } \\
\text { effectiveness throughout } \\
\text { your BSC study? }\end{array}$} & \multirow{3}{*}{ Teaching methods } & Student-centered & 27 \\
\hline & & Traditional & 59 \\
\hline & & Missing methods & 14 \\
\hline & \multirow{3}{*}{$\begin{array}{l}\text { Practical activities } \\
\text { of biology class }\end{array}$} & Ineffective lab & 42 \\
\hline & & Simple experiments & 14 \\
\hline & & Missing & 44 \\
\hline \multirow{5}{*}{$\begin{array}{l}\text { How do you explain the } \\
\text { assessment techniques } \\
\text { your } \\
\text { Instructors used } \\
\text { throughout your BSC } \\
\text { study? }\end{array}$} & \multirow{2}{*}{$\begin{array}{l}\text { Continuous } \\
\text { assessments }\end{array}$} & Tests & 28 \\
\hline & & Practical assignments & 2 \\
\hline & Exams & Termed exams & 70 \\
\hline & \multirow{2}{*}{ All over inputs } & Effective & 43.17 \\
\hline & & Ineffective or missing & 56.83 \\
\hline
\end{tabular}


Table 2. Observation checklists of trainees while conducting practical activities.

\begin{tabular}{|c|c|c|}
\hline Tasks & Status of performances of the variables & $\begin{array}{c}\text { Degree of } \\
\text { performance } \\
(\%) \\
\end{array}$ \\
\hline \multirow{2}{*}{$\begin{array}{l}\text { Discussing } \\
\text { the contents } \\
\text { knowledge of } \\
\text { biology }\end{array}$} & Better conceptualization and definitions & 32 \\
\hline & $\begin{array}{l}\text { Missing too much and posed to vulnerable } \\
\text { knowledge }\end{array}$ & 68 \\
\hline \multirow[b]{2}{*}{ Microscopy } & Understood some of the concepts & 18 \\
\hline & $\begin{array}{l}\text { Unable to understand and operate microscopes } \\
\text { easily }\end{array}$ & 82 \\
\hline \multirow{2}{*}{$\begin{array}{l}\text { Biology lab } \\
\text { activities }\end{array}$} & $\begin{array}{l}\text { Used lab equipment, observed objects and } \\
\text { reported }\end{array}$ & 31 \\
\hline & $\begin{array}{l}\text { Difficulties in using lab equipment, identifying } \\
\text { objects and writing up lab reports }\end{array}$ & 69 \\
\hline \multirow{2}{*}{$\begin{array}{l}\text { Simple } \\
\text { experiments in } \\
\text { biology }\end{array}$} & When demonstrated they try similar activities & 22 \\
\hline & $\begin{array}{l}\text { Incompetent to use equipment, chemicals and do } \\
\text { designated experiments of biology }\end{array}$ & 78 \\
\hline \multirow[b]{2}{*}{ Assignments } & $\begin{array}{l}\text { Some tried to write meaningless items for given } \\
\text { tasks }\end{array}$ & 42 \\
\hline & $\begin{array}{l}\text { Insufficient and incompetent to conduct the work } \\
\text { of excellence }\end{array}$ & 58 \\
\hline \multirow{2}{*}{$\begin{array}{l}\text { Over all task } \\
\text { performances }\end{array}$} & Conducted tasks across population & 29 \\
\hline & Unperformed biological tasks (incompetency) & 71 \\
\hline
\end{tabular}

\section{Discussion}

In Ethiopian higher education systems, most of the required instructional materials were inadequate and graduates were limited to certain irrelevant resources and depended on old copies of reading materials to complete prescribed courses for the undergraduate program of biology.

Reisberg, L. and Rumbley L. E. (2010) described that "most Universities of Ethiopia do not have the resources to effectively supervise or mentor so that many new and inexperienced instructors are assigned; research projects are often hand to less-experienced and less-qualified staffs that constrained the quality of education is". It displays that insufficient, little and impracticable knowledge were transferred to graduates, which finally made graduates to end with professional incompetence and joblessness. Teaching methods of the higher education systems were ineffective and biology graduates were not doing well by reasoning in meaningful and memorable ways to bridge the gap between theory and practice and enable them to execute professional works. 
Gharehbaghi, K. (2015) described that "effective pedagogy incorporates an array of teaching strategies that support intellectual engagement and connectedness to the wider world". The access to the new discoveries of biological researches with the ongoing global contexts was very scarce so that biology graduates were tightly blocked from the influxes of new information that could upgrade their understanding. Assessment techniques commonly used to measure, mark and rank biology graduates during their stay in the universities were termed tests that missed practical knowledge and corrective feedbacks within the time budget, in-actions and on-actions tasks. As outputs of the higher education learning, most of the graduates dissatisfy expected competences, lacked ability to demonstrate and perform activities related to the field of biology like the lab works and experiments.

In view of the higher education massification, Ashcroft, K. (2010) described that "the expansion of university systems can lead to financial constraints and deteriorating conditions of study. The Ethiopian system struggles to achieve more graduates without a noticeable loss of quality. The expansion of higher education institutions leads to more complex organizations, which requires more well-qualified administrative staff than are available, whose members have very limited abilities to develop systems to cope with more students and still lacks matching between employer and stakeholder requirements and the curriculum, pedagogy and assessment methods". Respectively, the condition is so far at serious disadvantages in finding sufficient instructional resources and qualified staffs of higher educational systems.

In view of this, the European commission report (2010b cited in 2011) states that "education and training can be effective and innovative only if the institutions themselves are innovative learning organizations and open to interactions with the world. Higher education systems must continue to evolve if they are to respond effectively to the skills needs of knowledge and challenges related to delivering high quality education to an even larger proportion of the population. At a fundamental level, this implies complementing the traditional academic culture in universities with a focus on producing a highly skilled, enterprising and flexible workforce, which in turn requires increased interaction between higher education institutions and the world around".

Higher education systems are expected to promote effective teaching methods that integrate practical activities to play essential roles in creating high quality of experience and enabling biology graduates the achievement of knowledge, competences and skills works. Teaching biology needs to concentrate on the delivery methods that address what and how a learner practically understands, avoid misconceptions and make use of the knowledge. But, the higher education system missed the ability to construct transferable competencies needed to succeed and skills to perform professional works after graduation. In reference to this point, UNISCO (2009) described that "good teaching would focus on what teachers do primarily on what students learn". It was due to the reason that most of the higher education systems ignored attentions to the development of thoughtful experience and responsibilities of imparting practicable knowledge to the students.

European Universities Association (2015) described that "institutions should ensure that the programs are delivered in a way that encourages students to take an active role in creating the learning process that assessments of students reflect the same approach, monitor, respond to the needs of students and society and review programs periodically".

Although many higher education institutions are currently trying to balance forces of instructional materials and educational systems to upgrade the quality to the levels of required standards, little results are gained in reality. The current higher education curricula 
are often slow to respond to the changing needs, not only in biology, but in the wider fields and fail to anticipate or shape careers that facilitate opportunities of finding jobs. Among the various systems of instructions proposed so far, modular instruction is one of the newly introduced teaching materials in which learning is either partly or entirely based on modules to alleviate the current problems of instructional materials shortages and may meet the needs of today's students more adequately with respect to the content knowledge and quality of learning than the traditional ways. In spite of this, biology graduates exercised little practical activities so that the time invested on learning remains wasted when the expected practical performances in biology remained ineffective.

The issue of capacity constructing to perform biological tasks after completing higher education deals with the concept to what extent learners have understood, retained gained experiences and constructed skills of pertinent works.

\section{Conclusions and Recommendations}

The scenario of the higher education institutions today mostly emphasizes on the extension and production of graduates in mass, which is mismatching and putting great negative impacts on the professional quality of graduates and ended with increasing the numbers of jobless. Overall, the relations between the current higher education teaching, learning and assessment efficiency or inputs were mostly divorced from the required quality of outputs or proficiency as well abilities of doing practical works. Although there are strong needs for innovative delivery methods to improve the quality of education, the escalating numbers of students joining the higher education institutions every year from different backgrounds, come up with the shortages of educational resources, facilities and qualified staff to administrate the programs.

Qualification in any profession is an experience accumulated throughout attaining the full chains of elementary, primary, secondary and higher education systems with substantial coverage of the prescribed contents and if any of the chains are corrupted, the outcome faces several disadvantages. In fact, practice is increasingly the dynamic agent of changes in the academic landscape, but graduates of biology achieved little experience in materializing the concepts of biology and exercising practically during their three years study and lost self- confidence on the degree they hold.

The summary of comparative evaluation of the higher education system inputs with the outputs in practices evidently mismatched so that the impacts of insufficient instructional materials and education systems including all schooling facilities have deteriorated the quality of higher education.

Higher education systems are expected to provide practicable knowledge and knowhow that could enable graduates to understand and do practically in relation to what they have learnt. Accordingly, the following points of solutions are recommended.

1. Ethiopian higher education systems require providing adequate instructional resources and facilities with qualified staffing who can transfer satisfactory know-how, sustain and provide practicable knowledge to graduates.

2. The instructional materials of biology of the higher education systems need to be consistent and content innovative to connect theory practice that enable graduates to perform professional tasks.

3. Assessing areas of strengths and weakness in-action and on-action, feedbacks and renovation of the materials could maintain the balances of teaching and learning and minimize the overwhelming impacts of bad teaching. 
4. Implementations of minds-on and hands-on activities in biology lessons provide the best methods of solving the impacts and challenges graduates of biology face in practice.

\section{References}

Ashcroft, K. (2010). ETHIOPIA: Dilemmas of higher education massification. University of Wales nstitute, Cardiff, UK.

European commission report (2010b). European Commission Working document on recent developments of European higher education systems. An agenda for the modernization of Europe's higher education systems as cited in European commission report (2011).

European Universities Association (2015). Standards and Guidelines for Quality Assurance in the European Higher Education Area: Endorsed by the Bologna Follow-Up Group Ministerial Conference. Yerevan.

Gharehbaghi, K. (2015). The importance of industry links in teaching pedagogy: A higher education prospective. International Journal of Contemporary Research, 5 (1), 17-23.

Reisberg, L., Rumbley, L. E. (2010). Ethiopia: The dilemmas of expansion. International Higher Education, 58 (Winter), 23. Retrieved from https://ejournals.bc.edu/ojs/index. php/ihe/article/view/8462/7596.

UNESCO Report (2009). Trends in Global Higher Education: Tracking an academic revolution, a report prepared for the UNESCO, 2009 World Conference on Higher Education (reported by Philip G. A., et al.).

Received 22 November 2016; Accepted 20 December2016

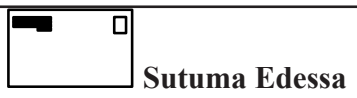

PhD., Researcher, Department of Science and Mathematics Education, College of Education and Behavioral Studies, Addis Ababa University, Ethiopia.

E-mail: Sutuma2006@yahoo.com 